(Житомирський державний університет імені Івана Франка) inna. konovalchuk@ukr.net ORCID: 0000-0002-9391-3786

\title{
ЕКСПЕРИМЕНТАЛЬНА ПЕРЕВІРКА МОДЕЛІ ПІДГОТОВКИ МАЙБУТНІХ УЧИТЕЛІВ ПОЧАТКОВИХ КЛАСІВ ДО ВЗАЕМОДІЇ З БАТЬКАМИ ТА ДІТЬМИ В СИТУАЦІЇ КОНФЛІКТУ
}

\begin{abstract}
У статті розглянуто результати перевірки ефективності моделі підготовки майбутніх учителів початкових класів до взаємодії з дітьми та батьками в ситуації конфлікту. Виокремлено послідовність, завдання, зміст, методи експерименту. Визначено критерії та рівні готовності, спроектовано педагогічні умови, спецкурс, технології, засоби підготовки майбутніх учителів до означеного виду діяльності. Результати експерименту засвідчили позитивну динаміку формування готовності майбутніх учителів початкової школи до роботи з батьками та дітьми в ситуації конфлікту між ними.
\end{abstract}

\section{Ключові слова: ситуаиія конфлікту, модель підготовки, готовність майбутніх учителів початкових класів до міжособистісної взаємодї̈ з дітьми та їх батьками в ситуації конфлікту, педагогічний експеримент, критерії готовності, рівні готовності.}

Постановка проблеми. Концепція Нової української школи базується на педагогіці партнерства між учнями, педагогами й батьками. Однак існуючий стан підготовки майбутніх учителів початкових класів до роботи з дітьми та батьками характеризується комплексом взаємопов'язаних суперечностей, а саме: об’єктивним існуванням конфліктів молодших школярів з батьками, що негативно вливають на особистісний розвиток і навчання дітей та ігноруванням цього факту як вчителями так і батьками; гострою потребою батьків у налагодженні конструктивних відносин 3 дітьми та недостатньою професійною готовністю учителів надати сім'ї кваліфіковану педагогічну допомогу; необхідністю системної підготовки майбутніх вчителів початкової школи до міжособистісної взаємодії з дітьми та їх батьками в ситуації конфлікту та невизначеністю завдань, змісту, технологій та організаційнопедагогічних умов цього процесу.

Аналіз останніх досліджень i публікацій. Обгрунтування теоретико-методологічних засад дослідження проблеми конфліктів, способів їх попередження та вирішення розроблені в працях А. Анцупова, О. Белкіна, О. Варги, Н. Гришиної, А. Захарова, Е. Ейдеміллера, С. Смельянова, О. Іонової, Г. Ложкіна, М. Пірен, Н. Пов'якель, В. Шейнова та ін. Питання підготовки вчителів до взаємодії з суб'єктами конфліктів у педагогічному процесі стали предметом наукових пошуків Г. Антонова, О. Березюк， Ю. Костюшка， Ю. Кулюткіна， А. Лукашенка， Л. Мільто， М. Рибакової， В. Семиченко, Г. Сухобської, У Шостак та ін. Науковці наголошують на провідній ролі та важливості спеціальної підготовки учителя як професійного посередника у вирішенні конфліктів дітей з батьками, педагогами, однолітками. Втім, незважаючи ці багатовекторні дослідження, питання формування готовності майбутніх учителів початкових класів до роботи 3 дітьми та батьками в ситуації конфлікту між ними залишаються невирішеними й актуальними.

Метою статті $\epsilon$ висвітлення програми, основних етапів та результатів експериментальної перевірки авторської моделі підготовки майбутніх учителів початкових класів до міжособистісної взаємодії 3 дітьми та батьками в ситуації конфлікту.

Виклад основного матеріалу. Значимість підготовки майбутніх учителів початкових класів до взаємодії з батьками та дітьми в ситуації конфлікту обумовлена тим, що молодший шкільний вік $є$ досить складним у формуванні особистісних якостей дитини. В цей період суттєво змінюються соціальна ситуація розвитку дитини, яка розширює сферу ії діяльності, активізує нові життєво важливі потреби та інтереси, а відсутність умов та можливостей їх повноцінної реалізації може призводити до виникнення конфліктних ситуацій з батьками. Практика показує, що більшість батьків не можуть самостійно вирішити конфліктні ситуації з власною дитиною і потребують кваліфікованої педагогічної допомоги, за якою вони в першу чергу звертаються до вчителя. Різноманітність та складність таких конфліктів потребує від учителя високого рівня відповідної професійної підготовки. Тому мета нашого експерименту полягала в обгрунтуванні та перевірці ефективності авторської моделі й технології формування готовності майбутніх учителів початкових класів до міжособистісної взаємодії з дітьми та батьками в ситуації конфлікту.

Провідним методом дослідження обрано педагогічний експеримент, в якому взяли участь 208 студентів спеціальності "Початкова освіта". Сформульована гіпотеза формувального експерименту полягала в тому, що підготовка майбутніх учителів початкових класів до налагодження конструктивної взаємодії дітей з батьками в ситуації конфлікту буде ефективною за таких організаційно-педагогічних 
умов: усвідомлення студентами можливих негативних наслідків дитячо-батьківських конфліктів та формування в них мотивації до оволодіння необхідними для їх вирішення знаннями й уміннями; обгрунтування та впровадження моделі формування готовності майбутніх учителів початкових класів до роботи $з$ дітьми та їх батьками в ситуації конфлікту між ними; розробки та введення у навчальний процес спецкурсу "Технології конструктивної взаємодії вчителя початкових класів 3 дітьми та батьками в ситуації конфлікту" з метою засвоєння студентами необхідних теоретичних знань, набуття практичних умінь та розвитку індивідуально-особистісних якостей; використання інтерактивних технологій навчальної діяльності студентів.

Експериментальна робота проводилась послідовно впродовж 2014-2018 рр. і передбачала реалізацію комплексу науково-теоретичних, діагностичних, методичних та організаційних заходів, які були реалізовані в декілька етапів: теоретично-пошукового, діагностично-аналітичного, формувального, результативно-узагальнюючого.

На теоретично-пошуковому етапі дослідження проведено вибір й аргументацію основних теоретичних підходів, уточнено систему базових понять, необхідних для розуміння сутності, змісту, розробки моделі й технології процесу підготовки майбутніх учителів початкової школи до міжособистісної взаємодії з дітьми та батьками в ситуації конфлікту. Концептуальними засадами розробленої моделі визначено основні положення та принципи міждисциплінарного, системного, діяльнісного, технологічного, задачного підходів та ідеї гуманізації, педагогіки партнерства, інноваційності, компетентності, що визнані стратегічними в Концепції Нової української школи.

Готовність учителя до міжособистісної взаємодії з дітьми та їх батьками в ситуації конфлікту розуміється нами як інтегративна якість його особистості, що виникає в результаті єдності сформованості особистісно-психологічної, теоретичної, процесуально-технологічної структур відповідної діяльності та є регулятором й умовою успішного вирішення дитячо-батьківських конфліктів. При цьому ми виходили 3 позиції І. Гавриш, що сутність готовності особистості до педагогічної діяльності виражається в діалектичній єдності всіх іï структурних компонентів, властивостей, зв'язків і відносин [1: 86]. Також ми враховували, що функціонально зміст готовності до певного виду діяльності має відповідати іiі структурі. В теоретичній моделі, запропонованій В. Семиченко, взаємодія розгортається у такій послідовності: потреби, мотиви, мета, зразки, умови, засоби, результат, корекція [2: 324]. У результаті аналізу представлених у науковій літературі підходів ми виділили такі структурні компоненти готовності майбутніх учителів початкових класів до взаємодії з батьками та дітьми в ситуації конфлікту: мотиваційно-ціннісний, пізнавальний, діяльнісно-практичний, регулятивний.

I. Дичківська, наголошує, що професійна готовність є закономірним результатом спеціальної підготовки, самовизначення, освіти й самоосвіти, виховання і самовиховання [3: 277]. Вважаємо, що процес підготовки доцільно розробляти як спеціально організовану навчальну діяльність студентів 3 логічною послідовністю етапів, з чіткою конкретизацією задач, змісту, форм, методів формування у майбутніх учителів здатності професійно надавати допомогу батькам і дітям у вирішенні їх міжособистісних конфліктів. Модель такого процесу побудовано як педагогічну систему, що відображає єдність теоретикометодологічних, змістових, технологічних і результативних складових підготовки майбутніх вчителів початкових класів до означеного виду діяльності. В результаті моделювання спроектовані необхідні педагогічні умови, зміст, організаційні форми, методи, засоби, цілісність реалізації яких забезпечує ефективність досягнення прогнозованих результатів підготовки.

На діагностично-аналітичному етапі експерименту проведено діагностику типових сфер та причин виникнення дитячо-батьківських конфліктів, аналіз наявного стану готовності працюючих та особливостей підготовки майбутніх учителів початкових класів до міжособистої взаємодії з дітьми та їх батьками в ситуації конфлікту. В процесі пошукового експерименту було діагностовано 110 учнів 1-4 класів та 89 батьків. В результаті виявлено та диференційовано п’ять сфер конфліктної взаємодії дітей 3 батьками: 1) сфера розуміння батьками психологічного віку дитини та ії вікових потреб (23,7\%), 2) сфера відносин батьків і дітей $(9,1 \%), 3)$ сфера навчальної діяльності дітей $(17,8 \%)$, 4) сфера позанавчальної діяльності дітей $(32,3$ \%), 5) сфера індивідуальних рис дітей (17 \%). Було встановлено, що 78 \% батьків потребують психолого-педагогічної допомоги у врегулюванні міжособистісних конфліктів 3 дітьми.

Для уточнення інформації опитано 56 учителів початкових класів. У результаті виявлено, що вчителі відчувають серйозні утруднення в діагностиці причин конфліктів дітей з батьками, розумінні природи їх виникнення та ескалації, застосування адекватних способів їх вирішення. Значна частина вчителів (32\%) узагалі не визнає наявності, гостроти та негативних наслідків конфліктів між дітьми та батьками саме в молодшому шкільному а не підлітковому віці.

Для аналізу стану підготовки вчителів початкових класів до міжособистісної взаємодії з батьками та дітьми в ситуації конфліктів у закладах вищої освіти було вивчено навчальні плани, навчальні та робочі програми, проаналізовано зміст дисциплін, форми проведення навчальних занять та їх обсяг. У результаті констатовано, що в процесі вивчення психолого-педагогічних та інших дисциплін не 
приділяється достатня увага формуванню у студентів знань і практичних умінь в організації взаємодії між дітьми та їх батьками при наявності конфліктів між ними. Варто зазначити, що у змісті цих дисциплін питання конфліктів дітей молодшого шкільного віку з батьками та діяльності вчителя 3 їх вирішення практично не представлені. В програмах педагогічних практик для студентів передбачено завдання - збір та аналіз педагогічних ситуацій. Однак оцінка результатів практик показала, що студенти в основному описують конфліктні ситуації, що виникають в учнів з учителями чи у взаємодії 3 однокласниками. Проблеми взаємовідносин дітей 3 батьками практично не попадають в коло спостережень студентів-практикантів. Це не може позитивно впливати на рівень їх професійної підготовки до майбутньої роботи з попередження та вирішення конфліктів між дітьми та батьками.

Пошуковий експеримент підтвердив реальну наявність описаних в психолого-педагогічній літературі конфліктів між молодшими школярами й батьками та недостатню готовність учителів до налагодження конструктивної взаємодії між ними, що обумовлює необхідність цілеспрямованих змін в цілях та змісті навчання студентів спеціальності "Початкова освіта".

Формувальний експеримент складався 3 послідовних етапів: констатувального - діагностики наявного рівня готовності майбутніх учителів початкових класів до міжособистісної взаємодії з дітьми та батьками в ситуації конфлікту, вибору контрольних та експериментальних груп; упровадження в експериментальних групах авторської моделі й технології підготовки студентів, зокрема, проведення спецкурсу "Технології конструктивної взаємодії вчителя початкових класів 3 дітьми та батьками в ситуації конфлікту", повторної діагностики в кінці експерименту для аналізу його результативності. У формувальному експерименті брало участь 208 студентів, з них 103 - експериментальна група, 105 контрольна. Рівень досліджуваної готовності в обох групах на початку експерименту практично ідентичний.

Теоретичний аналіз структури готовності майбутніх учителів початкової школи до міжособистісної взаємодії з дітьми й батьками в ситуації конфлікту дав можливість визначити критерії ії діагностики (ціннісно-мотиваційний, когнітивний, комунікативно-діяльнісний, рефлексивно-регулятивний). Виокремлено репродуктивно-емпіричний, адаптивний, конструктивний, творчий рівні можливої готовності студентів до означеного виду діяльності. До блоку методів діагностики сформованості компонентів готовності вчителів до міжособистісної взаємодії в ситуації конфлікту увійшли: опитувальник А. Реана "Мотивація успіху і боязнь невдачі", самооцінка рівня індивідуальної конфліктності особистості, методика І. Юсупова, метод експертних оцінок, тести на визначення рівня конфліктологічних знань студентів.

Аналіз результатів діагностики на констатувальному етапі експерименту показав: переважна більшість студентів як контрольної так і експериментальної груп мають адаптивний (КГ - 39,81 \%, ЕГ $38,47 \%$ ) та репродуктивно-емпіричний (КГ - 38,65 \%, ЕГ - 39,18\%) рівні готовності до міжособистісної взаємодії з дітьми та батьками в ситуації конфлікту і досить малий відсоток - конструктивний (КГ $16,92 \%$, ЕГ - 17,21 \%) та творчий (КГ - 4,62 \%, ЕГ - 5,14\%) рівні.

За показниками ціннісно-мотиваційного критерію в студентів виявлено низький рівень мотивів до роботи 3 дітьми й батьками, які мають проблеми у взаємовідносинах. Студенти не повною мірою усвідомлюють негативний влив конфліктів молодших школярів з батьками на особистісний розвиток та становлення самооцінки дітей, а також професійні функції вчителя у вирішенні таких ситуацій. Майбутні вчителі відчувають невпевненість і навіть страх, що не зможуть допомогти батькам у складних конфліктних ситуаціях з дітьми через відсутність відповідної підготовки.

За когнітивним критерієм готовність майбутніх учителів характеризується низьким рівнем спеціальних знань про дитячо-батьківські конфлікти. Встановлено, що знання студентів про психологопедагогічні особливості конфліктів дітей молодшого шкільного віку з батьками в основному мають поверхневий характер. Вони не можуть пояснити причини виникнення таких конфліктів, обгрунтувати їх взаємозв'язок з віковими закономірностями розвитку дітей.

Визначення рівня сформованості комунікативно-діяльнісного компонента готовності до взаємодії 3 дітьми та батьками проводилася на основі експертної оцінки можливостей студентів професійно розв'язувати спеціально підібрані ситуації-моделі конфліктної взаємодії дітей з батьками. Отримані результати підтвердили, що без спеціальної підготовки запропоновані студентами рішення конструюються на основі особистого емпіричного досвіду чи адаптації власних моделей поведінки в конфлікті до ситуацій, що потребують професійного рівня роботи з дітьми та батьками. Діагностика за рефлексивно-регулятивним критерієм показала, що більшість майбутніх учителів не усвідомлюють необхідності та не вміють оцінювати й регулювати свої дії у взаємодії з дітьми та батьками в ситуації конфлікту з позиції професійних обов'язків та етики.

Враховуючи недостатній рівень готовності майбутніх учителів початкових класів до конструктивної міжособистісної взаємодії з дітьми та їх батьками в ситуації конфлікту на формувальному етапі експерименту була здійснена перевірка ефективності авторської моделі й технології їх підготовки до означеного виду діяльності. В навчальний процес експериментальної групи студентів було внесено зміни 
в зміст дисциплін професійної підготовки, визначені можливі способи інтеграції знань через встановлення міжпредметних зв’язків у процесі їх практичного застосування. 3 метою систематизації підготовки студентів упроваджено спецкурс "Технології конструктивної взаємодії вчителя початкових класів з дітьми та батьками в ситуації конфлікту". Для вироблення у майбутніх учителів практичних умінь надання допомоги батькам у вирішенні проблем взаємовідносин з дітьми застосовано інтерактивні педагогічні технології. В процесі індивідуально-самостійної роботи студенти здійснювали пошук та опрацювання тематичної інформації, готували повідомлення, презентації. Для засвоєння понять 3 конфліктології студенти складали термінологічний словник. Теми 3 означеної проблематики були внесені до списку курсових робіт з педагогіки й психології. Також відкореговано завдання $з$ педагогічної практики. В навчанні студентів контрольної групи змін не було.

Спецкурс "Технології конструктивної взаємодії вчителя початкових класів з дітьми та батьками в ситуації конфлікту" був спрямований на засвоєння студентами системи теоретичних знань про психолого-педагогічні причини, типи та сфери конфліктів молодших школярів з батьками, а також на формування комплексу умінь: діагностувати, аналізувати конфліктні ситуації, знаходити й реалізовувати оптимальні способи їх попередження та вирішення, здатності самостійно оцінювати та регулювати свою діяльність в процесі роботи з дітьми та батьками.

Зміст навчального матеріалу побудовано дотримуючись наступних принципів: взаємодії навчальнопізнавальної, навчально-практичної та самостійної практичної діяльності студентів, єдності процесуально-змістовних і мотиваційно-ціннісних сторін педагогічної підготовки, єдності й інтегрованості змісту навчання [4: 98]. Тому при подачі теоретичного матеріалу ми прагнули викликати інтерес студентів до проблеми конфліктів дітей з батьками, пояснити функції вчителя у їх вирішенні, стимулювати потреби професійного саморозвитку. Для цього використовувалися такі методи як: лекціядискусія, проблемна лекція, евристична бесіда, метод аналізу конкретних ситуацій, які активізують творче, дивергентне мислення, стимулюють до пошуку та освоєння необхідної, щоб знайти власне рішення запропонованих педагогічних задач, інформації.

Процесуально-діяльнісний блок моделі підготовки майбутніх учителів початкових класів до міжособистісної взаємодії з дітьми та їх батьками в ситуації конфлікту був спрямований на формування практичної готовності студентів і в спецкурсі реалізовувався шляхом моделювання і розв'язання професійно-орієнтованих педагогічних задач, аналізу ситуацій-вправ, проведення ділових та рольових ігор, педагогічного тренінгу. Широко використовувалися інтерактивні методи - мозковий штурм, формулювання задач, евристична бесіда, метод колективного блокнота, метод "кейс-стаді" тощо. Такі методи сприяють розвитку мотивації студентів до самонавчання, умінню формулювати, висловлювати та аргументувати власні думки, здатності аналізувати та моделювати оптимальні варіанти вирішення конфліктів дітей з батьками.

Одним із завдань педагогіки вищої освіти А. Алексюк визначає трансформацію проблемної ситуації в статус навчальної проблеми. Проблема повинна становити інтерес для студента, бути сприйнятою ним, щоб почати іiі розв'язання. Це має місце лише тоді, коли поставлена проблема спирається на наявні знання студента, і водночас він розуміє, що їх не достатньо для іiї вирішення [5: 426]. Для вирішення цього завдання у навчанні студентів цілеспрямовано застосовувався метод моделювання педагогічних ситуацій, враховуючи, що його можливості забезпечують: пізнання об'єкта, що моделюється; включення студентів у інтерактивну навчальну діяльність; визначення проблем та протиріч, що підлягають вирішенню; формування теоретичної основи й практичних умінь професійної взаємодії; вироблення індивідуальних моделей поведінки у ситуаціях професійної взаємодії [6: 68]. Моделювання конфліктних ситуацій виступає засобом активізації навчальної діяльності студентів, усвідомленого використання теоретичних знань та оцінки їх достатності для професійного рівня діяльності, формування необхідних умінь та навичок. Мінітренінги були спрямовані на розвиток професійно важливих особистісних якостей студентів - потреби в самооцінці та саморефлексії своєї конфліктологічної компетентності, комунікабельності, умінню слухати, розуміти й приймати позиції інших людей, впевненості, відповідальності, толерантності, креативності та ін..

На результативно-узагальнюючому етапі експерименту було проведено повторний діагностичний зріз. Аналіз та порівняння вихідних та кінцевих даних дозволяє дійти висновку про те, що показники рівня сформованості складових готовності студентів до міжособистісної взаємодії з дітьми та батьками в ситуації конфлікту в експериментальних групах зазнали більш суттєвих позитивних змін, ніж в контрольних групах. Динаміка зрушень у показниках рівня готовності студентів за ціннісномотиваційним критерієм в експериментальних та контрольних групах відповідно становить: творчий рівень: $+11,5 \%$ та $+3,1 \%$; конструктивний: $+19,2 \%$ та $+6,4 \%$; адаптивний: $-11,3 \%$ та $-4,1 \%$; репродуктивно-емпіричний: $-21,5 \%$ та $-5,9 \%$. В учасників експерименту виявлено значні позитивні зміни сформованості готовності до роботи 3 дітьми та батьками в ситуації конфлікту між ними за когнітивно-інформаційним критерієм в експериментальних та контрольних групах відповідно: творчий рівень: $+12,5 \%,+3,8 \%$; конструктивний рівень: $+31,4 \%,+7,9 \%$; адаптивний: $+23,2 \%,+6,4 \%$; 
репродуктивно-емпіричний: $-53,8 \%,-12,4 \%$. Встановлено позитивні зміни в рівнях готовності майбутніх учителів до взаємодії з дітьми та батьками в ситуації конфлікту за комунікативно-діяльнісним критерієм відповідно в експериментальних та контрольних групах: творчий рівень: $+9,5 \%$ та $+4,8 \%$; конструктивний: $+27,2 \%$ та $+6,3 \%$; адаптивний: $-14,3 \%$ та $-4,1 \%$; репродуктивно-емпіричний: $20,4 \%$ та $-5,8 \%$. Зіставлення результатів констатувального та формувального етапів експерименту свідчить про різний відсоток зростання рівня рефлексивно-регулятивної готовності студентів до самооцінки та корекції своєї поведінки у взаємодії з дітьми та батьками в ситуації конфлікту відповідно в експериментальних та контрольних групах: творчий рівень: $+9,1 \%$ та $+3,9 \%$; конструктивний: $+22,3 \%$ та $+6,7 \%$; адаптивний: $-17,2 \%$ та $-4,1 \%$; репродуктивно-емпіричний: $-22,4 \%$ та $-6,8 \%$. Перевірка результатів експериментального дослідження за допомогою $\varphi$ - критерій кутового перетворення Фішера підтвердило їх достовірність.

Висновки та перспективи подальшого дослідження проблеми. Результати експерименту показали, що впровадження авторської моделі дає стійку тенденцію до зростання готовності майбутніх учителів початкових класів до роботи $з$ дітьми та їх батьками в ситуації конфлікту між ними. Ефективність такої підготовки забезпечується створенням відповідних організаційно-педагогічних умов для усвідомлення студентами значимості дитячо-батьківських конфліктів у розвитку особистості дитини, актуалізації мотивів здобуття необхідних для їх професійного вирішення знань та умінь, введенням у навчальний процес спецкурсу із застосуванням інтерактивних технологій навчання. Перспективи подальших досліджень полягають у вдосконаленні змісту та навчально-методичного забезпечення підготовки майбутніх учителів початкових класів до реалізації педагогіки партнерства в умовах Нової української школи.

\section{СПИСОК ВИКОРИСТАНИХ ДЖЕРЕЛ ТА ЛІТЕРАТУРИ}

1. Гавриш І. В. Теоретико-методологічні основи формування готовності майбутніх учителів до інноваційної діяльності : дис. ... д-ра пед. наук : 13.00 .04 / І. В. Гавриш. - Х., 2006. - 572 с.

2. Семиченко В. А Психологія педагогічної діяльності : [навч. посіб.] / В. А. Семиченко. - К. : Вища школа, 2004. $-335 \mathrm{c}$.

3. Дичківська I. М. Інноваційні педагогічні технології : [навчальний посібник] / І. М. Дичківска. - К. : Академвидав, 2004. - 352 с.

4. Педагогіка вищої школи : [навч. посіб.] / [Курлянд 3. Н., Хмелюк Р. І., Семенова А. В. та ін. ; за ред. 3. Н. Курлянд]. - [2-ге вид., перероб. і доп.]. - К. : Знання, 2005. - 399 с.

5. Алексюк А. М. Педагогіка вищої освіти України. Історія. Теорія : підручник для студентів, аспірантів та молодих викладачів вузів / А. М. Алексюк. - К. : Либідь, 1998. - 558 с.

6. Шигонська Н. В Підготовка студентів медичних спеціальностей до професійної взаємодії засобами моделювання комунікативних ситуацій : дис. ... канд. пед. наук :13.00.04 / Н. В. Шигонська. - Житомир, 2011. $-246 \mathrm{c}$.

\section{REFERENCES (TRANSLATED \& TRANSLITERATED)}

1. Gavrysh I. V. Teoretyko-metodologichni osnovy formuvannia gotovnosti maibutnikh uchyteliv do innovatsiinoi profesiinoi diial'nosti [Theoretical and Methodological Bases for the Formation of Future Teachers' Readiness to the Innovative Professional Activity] : dys. ... doktora ped. nauk : 13.00.04 / I. V. Gavrysh. - Kharkiv, 2006. - 572 s.

2. Semychenko V. A Psikhologiia pedahohichnoii diyalnostii [Psychology of Pedagogical Activity] : [navch. posib.] / V. A. Semychenko. - K. : Vishcha shkola, 2004. - 335 s.

3. Dychkivs'ka I. M. Innovatsiini pedagogichni tekhnologii [Innovational Pedagogical Technologies] : [navch. posib.] / I. M. Dychkivs'ka. - K. : Akademvydav, 2004. - 352 s.

4. Pedahohika vishchoii shkolu [Pedagogy of High School]: [navch. posib.] / [Kurlyand Z. N., Hmelyuk R. I., Semenova A. V. ta in. ; za red. Z. N. Kurlyand]. - [2-ge vyd., pererob. i dop.]. - K. : Znannya, 2005. - 399 s.

5. Aleksyuk A. M. Pedagogika vyshchoi osvity Ukrayiny : Teoriia [Pedagogy of Higher School] : [pidruch. dlya stud., asp. vuziv] / A. M. Aleksyuk. - K. : Lybid, 1998. - 560 s.

6. Shygonska N. V. Pidhotovka studentiv medychnykh special'nostei do profesiinoii vzaiemodii zasobamy modeluvannia komunikatyvnykh sutuatsii [Training the Medical Students to the Professional Interaction by Means of Communicative Situations Modeling] : dys. ... kand. ped. nauk :13.00.04 / N. V. Shygonska. - Zhytomir, 2011. $246 \mathrm{~s}$.

\section{Коновальчук И. Н. Экспериментальная проверка модели подготовки будущцх учителей начальных классов к взаимодействию с родителями и детьми в ситуации конфликта.}

В статье рассмотрено результаты проверки эффективности модели подготовки будущих учителей начальных классов к взаимодействию с детьми и родителями в ситуачии конфликта. Выделены последовательность, задачи, содержание, методы эксперимента. Определены критерии и уровни готовности, спроектировано педагогические условия, спецькурс, технологии, средства подготовки будущих учителей к указанному виду деятельности. Результаты эксперимента показали 
положительную динамику формирования готовности будущих учителей начальной школь к работе с родителями и детьми в ситуации конфликта между ними.

Ключевые слова: ситуация конфликта, модель подготовки, готовность будущих учителей начальных классов к межличностному взаимодействию с детьми и их родителями в ситуации конфликта, педагогический эксперимент, критерии готовности, уровни готовности.

\section{Konovalchuk I. M. Experimental Test of a Model of Prospective Teachers Training to Interact with Parents and Children in Conflict Situation.}

In the article the test results of a model effectiveness of the prospective teachers training interaction with parents in a conflict situation are viewed. The sequence, tasks, essence, methods and results of theoretical research, diagnostic analytical, forming and result generalizing steps of experiment are outlined. For the complex evaluation the value motivational, cognitive informational, communicative active, reflexive regulatory criteria, reproductive empirical, adaptive, constructive, cognitive levels of readiness of prospective teachers to personal interaction with children and their parents in a conflict situation are determined. At the stage of constative experiment the unsatisfactory level of readiness of prospective primary school teachers to the outlined activity has been discovered. The model reflects unity of theoretical methodological and practical technological components of preparation of prospective primary school teachers to personal interaction with children and their parents in a conflict situation.

Creation of author's model and testing its effectiveness were achieved through extracting the potential and adding to the essence of professional preparation of prospective teachers disciplines, tasks of all kinds of pedagogical practice, individual and scientific thematic research of the students, development and introduction of "Technologies of constructive interaction of primary school teacher with children and parents in a conflict situation" special course. Results of forming experiment have evidenced positive dynamics of readiness formation of prospective primary school teachers to work with parents and children in a situation of conflict between them.

Key words: conflict situation, model of preparation, readiness of future primary school teachers to personal interaction with children and their parents in a conflict situation, pedagogical experiment, criteria of readiness, levels of readiness. 